\title{
The Development of Reference Model for Social Commerce E-Marketplaces based on Value Co-Creation Framework
}

\author{
Alaa Moued Alharthi \\ Information System Department \\ Faculty of Computing and Information Technology \\ King Abdulaziz University, Jeddah
}

\author{
Salha Abdullah \\ Information System Department \\ Faculty of Computing and Information Technology \\ King Abdulaziz University, Jeddah
}

\begin{abstract}
Social commerce is an emerging phenomenon, is a novel form of e-commerce encompasses social media. Social commerce represents potential merchandising opportunities that combine shopping and social networking activities through social media. Social commerce presence increased within social networks and as well creates economic value through these networks. The restructuring of social commerce has been occurring, with an emphasis on the search for new business strategies and models that will be competitive in the digital global economy. Some of these restructurings include models to facilitate customers experience, new business strategies, and value co-creation between firms and their customers. Thus, social commerce needs to survive, this depends on online social networking, with its innovations in functionality, its integration with commerce activities, and its mechanisms for promoting social interactions and trust principle between firms and their customers. This goal of the research is to develop a model for social commerce with its functional requirements model with an understanding of value cocreation concept.
\end{abstract}

\section{General Terms}

Social Commerce.

\section{Keywords}

Social Commerce, E-marketplace, Value Co-creation, DCC Model, Technological Features.

\section{INTRODUCTION}

The revolution of the Internet shift people attention from traditional markets to electronic markets, because of the ease of exchanging goods, services, information, and payments. Also, social media has rapidly developed in the Internet world. As a result, people use social media in electronic markets, which create social commerce. Social commerce sites co-create value for companies and customers. Value cocreation importance is to use customer's experience and knowledge and focus on customer's opinion. This article contains two parts. Firstly, the literature reviews on emarketplaces, social commerce, and value co-creation. Secondly, the proposed model for social commerce emarketplaces based on value co-creation, which is a mapping between the value co-creation, model build based on different value co-creation frameworks and social commerce emarketplaces technological features.

\section{LITERATURE REVIEW}

\subsection{E-Marketplaces}

E-marketplace plays a major role in the digital economy because it makes the exchange of payments, goods, information, and services easier. E-marketplace has an economic value for sellers, buyers, society and market intermediaries. There are no limits for space, borders, or time in e-marketplace because it is a virtual market. There are a lot of definitions on e-marketplace, most of them agreed that an e-marketplace is an electronic place where selling and buying occurs. Turban et al. [1] defined an e-marketplace as space where buyers and sellers electronically meet and make transactions in different ways. Liberati [2] definition was an electronic market based on the Internet allows transactions and communications for online business-to-business. Kaur et al. [3] stated that the e-marketplace is the interaction of sellers and buyers through an inter-organizational system. Emarketplace can be a consumer-to-consumer (C2C), businessto-business (B2B), or business-to-consumer (B2C). Sellers and buyers can exchange services and goods, even if they are at different locations. Turban et al. [1] divided e-marketplace into two types:

- Web stores: refers to a website owned by one company or one seller to sell services and products.

- E-mall: similar to a real-world mall. It is one location where many sellers show their online catalog.

The key components of e-marketplace are products, customers, sellers, front and back-end infrastructure, intermediaries, support services and services (physical and digital):

- Customers: Every Internet user is a possible buyer for any services or goods on the Internet.

- Sellers: Every web store owner offers goods or services can be a seller. The seller can be individuals, companies, or government agencies.

- Products and services: e-marketplaces and traditional markets are both sell physical and digital products and services. The main difference between e-marketplaces and the traditional markets is the possibility of making goods or services digital online, at any time and from anywhere in seconds.

- Infrastructure: In general supports include software, hardware, databases, networks and more.

- Front-end: The interaction between customers and emarketplaces through a front end. Front-end consists of the portal, search engine, shopping cart, electronic catalogs, auction engine, and more.

- Back-end: The back-end activities are related to inventory management, payment processes, insurance, delivery, packaging, finance and order collection.

- Intermediaries: are the third party who works between buyers and sellers. They are managing the online market; matching sellers and buyers, helping them complete transaction. 
E-marketplaces have a lot of benefits for buyers and sellers. They are the availability of e-marketplaces at any time from anywhere providing great transparency and removing any problems and constraints of time, presence in different places while trading online for e-marketplace participants, time reduction between buying process and owning the product, information misunderstanding reduction between buyers and sellers. The time for searching for the information is lower in e-marketplaces than in physical market, easy to get the best deal because of the updated information, offering proper ways for buyers to compare prices and products from one source. It is considered as an additional sales channel to market, providing international deals for sellers because of the use of the Internet. E-marketplaces prices are often less than traditional markets.

In conclusion, a lot of people trade online nowadays because e-marketplaces make selling and buying processes easier and faster than traditional markets. Recently, many e-marketplaces use social media in their websites because of the improvements in the technologies of web 2.0. E-marketplaces use social media to gain valuable feedback on services and products [4]. The use of social media in e-marketplaces is called social commerce, which will discuss in the next section.

\subsection{Social Commerce}

The social commerce is an emerging concept conceived in 2005 [5][6] because of the increasing use of social media. There are many definitions written, but most researchers agreed that social commerce is a type of e-commerce that uses social media. Hajili [4] defined social commerce as the customers' interactions through social media such as recommendations, ratings, reviews, and online forum. Social commerce is a part of e-commerce and relation-based online business [5]. Finally, social commerce is the evolution of ecommerce, and it has more interaction and social than ecommerce [7].

Firms that choose to work with social commerce technology will gain benefits like drive visitors to sales, increase customers, engagement, revenue and profit, and conversation rates at lower cost from a traditional way of any improvements. According to Chen et al. [8], social commerce has benefits for both customers and sellers. Customers can pay less for purchases, develop relationships and help other customers and sellers, find new product and service through a social network, use social network pages to search, chat, and buy easily. Sellers can save money on customer service through Web 2.0 and self-service, identify problems quickly, compare prices to competitors, improve customer services, improve the design, get an advertisement for free, and increase profit. Customer feedback let sellers test new products and services inexpensively and quickly and let them learn about their customers.

Social commerce connects individual customers or firms to its consumer. From this point, researchers' opinions about social commerce types are divided into two parts. Firstly, social commerce is C2C (consumer-to-consumer) [5]. Secondly, social commerce is B2C (business-2-consumer) [6].

From a C2C perspective, social commerce has four characteristics [5]. First, they are individual sellers instead of firms. Second, sellers produce products and organizing them as specialized online shops. Third, sellers can make their shops hyperlinks with each other. Fourth, sellers' incentives are based on being paid commissions on their shops' sales. From a B2C perspective, the social commerce characteristics are the same, but the sellers are firms instead of individuals.

There are significant drivers of social commerce, the increasing of friends' recommendations, the ease of accessing them, the need to make customer satisfy, the need to collaborate with partners, and the real-time communications with friends [9].

Internet customers are called social customers. "The social customers have more power than regular customers. They can search for detailed information, compare prices, bid, and sometimes negotiate" [1]. Social customers are social networks users who interact to see services and products of each other, shop online, and know their rights and know how to use social communities to gain benefit. Friends and family are affected social customers. They are different from traditional customers, so sellers have to give them socially based service. Since customers use social media, they became more powerful and treated better than traditional customers. They are not just buyers, but they influence others.

Social commerce and e-marketplace have a lot of differences. For example, the purchases in social commerce are managed through the seller's website and social media while in emarketplace are managed through the seller's website. Other difference is customer interaction, wherein social commerce customers share their experiences either before, during, or after a purchase process which lead to bring other customers to visit the website. On the other hand, e-marketplace customers interact with employees to talk or ask questions.

Liang et al. [10] described that technologies and infrastructures of the Web 2.0 social media are used in social commerce to support online interaction and contributions between buyers and sellers to help to gain services and products.

O'Reilly [11] create the term web 2.0. It is the second phase of the web. Users in web 2.0 can easily create content, collaborate, share media, and communicate innovatively. Web 2.0 has five characteristics: community, connectivity, creativity, convergence, and collaboration. Really Simple Syndication (RSS), Mashups, Blogs, Wikis, and Tags are technologies used in web 2.0. Significant differences of web 2.0 are creative reuse, updates, and design become easier, provides a better user interface, create and modified content collaboratively, people with common interests are communicated through social networks, and supports collaboration and social nature.

With the increase in seeking to invest in social media seller's efforts, social commerce tools are growing. The following tools are developed to organize social commerce:

- $\quad$ Social Shopping

This tool lets people share their online shopping performance. Examples of this tool are co-browsing, askyour-network, group buying, social shopping portals, group gifting, and social network storefronts.

- Ratings and Reviews

This tool responsible for product or services evaluation, and enable others to discuss and contribute. Ratings and Reviews tool includes Expert and Customer Ratings and Reviews, Customer Testimonials, and Sponsored Reviews.

- Recommendations and Referrals

This tool encourages recommendations and referrals by social media, and sometimes sellers give rewards for everyone who recommends their sites. Social Recommendations, Share with Your Network, and 
Referral Programs are within this tool.

- Forums and Communities

This tool connects buyers or potential buyers with each other or with a business in an organized environment. Forums and Communities tool includes Questions and Answers (Q\&A) Forums, Idea Boards, User Forums, Brand Communities, and User Galleries.

- $\quad$ Social Media Optimization (SMO)

The purpose of this tool is attracting people to websites through social media advertising. This tool includes Link Building, Media Sharing, News Feeds, and Social Media Events.

- $\quad$ Social Advertisement and Application

Branded contents are written in social media either by social applications or advertisements. This tool includes social Ads and Social Apps.

Other tools are sharing rewards, easy social sharing, and product selection, implementing beautiful and big product images and product videos, product images must be attractive and significant, product titles should be descriptive, detailed product descriptions, display cost savings, (Favorite) feature for membership, updated product stats, social networking button (like, tweet, share), on-site search engine, accurate delivery and returns information, mobile applications beside websites, Frequently Asked Questions (FAQ) page, security features (firewalls, privacy policy, and username and password authentication), and easy and secure payment process.

In conclusion, the growth of social media and Web 2.0 technology makes social commerce the best on the online shopping area. The direct interaction and co-creation between customers and business are important for the company to success. With the use of technologies of Web 2.0, social commerce allows co-creation of value.

\subsection{Value Co-Creation}

Vargo et al. [12] explained that value is something gained and co-created upon use. Thus, a value is the feeling of satisfaction that the customer gets after being assisted in a service process. Hassan and Toland [13] defined value as what customers gain from the transaction of selling and buying. Companies create value from their resources for customers who increase sales and revenue. Customers cannot be seen as separated, passive, and unaware users of the emarketplace [14]. Customers should be connected, active, and informed to interact with firms to co-create value. Prahalad and Ramaswamy [15] defined value co-creation as the collaboration between sellers and customers to create value and the co-creator are customers. Value co-creation is essential because the companies shift their focus to customers and how to make them satisfied. In Flor and Maglio [16], the case study explained the role of the customers, and they model a representational business activity online. The focus of the model was to customers and how they played a significant role in the business process. Co-creation involves personalized interactions between firms and customers. According to Lyons and Tracy [17], a value from service system aspect is something realized from interactions and cocreation among the system. The outcome of service system entities interaction is always a value co-creation. There are three primary activities that service system engaged to cocreate value. They are suggesting an interaction to co-create value to different service systems, accept the suggestion, and realizing the suggestion [12].

$\mathrm{Ng}$ et al. [18] proposed seven Attributes for Value Co-creation
(AVC), which are complementary competencies, process alignment, behavioral alignment, perceived control, empowerment for the customer and firm transformation, behavioral transformation, and congruence of expectations. These attributes can change firms' organization to co-create more value with customers.

To co-create value, researchers suggested different frameworks and different studies exploring how the process of co-creation takes place. One of these proposed by Prahalad \& Ramaswamy [19] which is Dialogue, Access, Risk, Transparency (DART) Model. This framework used for value co-creation. It composes of dialogue, access, risk assessment, and transparency. Dialogue provides communications between producers and customers. Access provides to customers' access to resources, information, and tools. Risk means the customers know about the risk in the co-creation process. Transparency provides trust between customers and producers.

Ramaswamy [20] showed how Nike used the DART model to co-create value with its customers. Nike collaborated with Apple, and with use of the DART model, the (Nike +) platform was launched. Nike in this platform, use dialogues between a customer (runner) and Nike, between customer and Apple, and between runners and running experts. Nike provided access to customers through the device attached to their shoes and Nike + website. Nike risk assessment reduced the probability of customers getting hurt by suggesting for them proper training methods. Nike showed transparency by providing an extensive range of information about running, and routes. The benefits of using DART model for Nike is "high-quality co-creative interactions between runners, groups (teams of runners, running clubs)" [20] and organization.

Another value co-creation framework is Process-Based framework suggested by Payne et al. [21]. This framework provides structure for customers' involvement. It consists of three components: "customer value-creating processes, supplier value-creating processes, and encounter processes" [21]. Customer value-creating processes are about all resources, practices, and process that used by customers to do their activities. Supplier value-creating processes are about all resources, practices, and process that used by firms to deal with customers and partners. Encounter processes encounter processes of exchange and interaction.

Payne et al. [22] studied their proposed framework in Finland by applying it to the City Car Club (CCC). After the researchers had gathered data, they found out that many of the CCC's relationship with its members. Members used technology like e-mail, Internet, and mobile phone to provide opportunities to co-create value. After that, the researchers identified the objectives of planning and developing the framework. From the supplier side, the implementation phase was carried out, determining the subsequent encounters used to co-create experiences within each relationship phase. Then they mapped processes by using different channels, understanding the transactions and interactions between the consumer and seller, and defining how they can improve value co-creation. The result was designing specific encounters and mapping customer reactions to the client side of the encounter process [22].

The final framework example is Service-Dominant Logic (SDL) proposed by Vargo and Lusch [23]. SDL is considering as a basis for a comprehensive model of innovation, as a result of its focus on the notion of value co-creation. In IBM and Cambridge University Institute for Manufacturing, SDL is 
specifying as a possible theoretical basis for service science SDL focuses on relationships, process, and value co-creation.

Lubrica et al. [14] developed a reference model for B2B companies and applied the SDL framework to it. The primary objective was to understand the implications of the servicedominant logic and the value co-creation concept in the evolution and performance of an e-marketplace. The researchers validated the reference model on Malaysian wood companies. The EEE Encounter was the name of the proposed reference model. It includes: explore, exploit, and establish. The model proposes that an e-marketplace should have functionalities that allow buyers and sellers to perform the EEE Encounter model for value co-creation to take place. Explore means buyers and sellers can see services of each other. Exploit means buyers and sellers offered to each other knowledge and resources. Establish is about the relationship between buyers and sellers and how this relationship can lead to partnership [14].

Social commerce is an essential concept in the era of social media and networking. Companies are rushing to use social media into their online business. A model is needed to lead and assist companies to use social media with value cocreation with their customers into their online business. There are few studies discussed social commerce but from modeling design perspective [24] [25] [26]. Therefore, there is no work on social commerce e-marketplace based on value co-creation that had been done. This article will use social commerce and value co-creation fundamentals to develop a model for social commerce e-marketplace.

\section{DCC SOCIAL COMMERCE MODEL}

The features of social applications used in social commerce foster the contribution and interaction of the user to make online selling and buying process easier. To create websites more socially, business owners need to implement features that meet their customers' needs. Thus, to accomplish this, businesses need to consider what their customers like and what they need from social commerce websites by working with them to create better value, this step called value cocreation. Value co-creation offers an important chance to improve social commerce markets. Customers are the subjects of relationships who participate and collaborate with firms to co-create value [27].

Most of the researches done on value co-creation frameworks were for business industry without using any technology as in Attributes for Value Co-creation (AVC) [18], DART model [19], and Process-Based framework [21]. After a lot of researches done on social commerce e-marketplaces based on value co-creation, no models were found. Using social commerce e-marketplaces technological features helping business owners to design new services or products or to develop existing services or products with the support of their customers. They are important to facilitate value co-creation. Social commerce e-marketplaces technological features are using social media applications in traditional e-marketplaces websites. Each one of these features is software integrated into e-marketplace websites for sharing information in a better way and interacting socially. Co-creation in the physical world is different from the virtual world. In virtual world value co-creation between business owners and their customers increased because social commerce technological features make customers active, more collaborative, and the communication with customers direct, on time, continuously, and bidirectional with lower cost, higher efficiency and more involvement than classical communication tools [28].
In this part of the article, a model called DCC Social Commerce model, where DCC stands for Discovery, Communication, and Collaboration. It is presented for social commerce e-marketplaces based on different value cocreation frameworks and different works of literature on emarketplaces, social commerce, and value co-creation. The DCC social commerce model is a mapping between the DCC model build based on different value co-creation frameworks and social commerce e-marketplaces technological features.

This article contains three sections; the first section will discuss the model creation based on different value cocreation frameworks selected from different case studies. The second section will be about the technological features of social commerce e-marketplaces derived from multiple resources. The last section maps between the model and the technological features to show the effectiveness of the model on social commerce e-marketplaces.

\subsection{Model}

The DCC model is consists of three phases to co-create the value between business owners and their customers in any social commerce e-marketplace. The first phase, i.e., Discovery focuses on the ability of business owners and their customers to see the service presented from both of them. The second phase, i.e., Communication is the trust, obligation, and communication between business owners and their customers. The third phase, i.e., Collaboration is the ability of business owners and their customers to offer resources and knowledge for both of them (see Figure 1).

The value co-creation frameworks used to build the DCC model are Attributes for Value Co-creation (AVC) [18], DART model [19], and Process-Based framework [21]

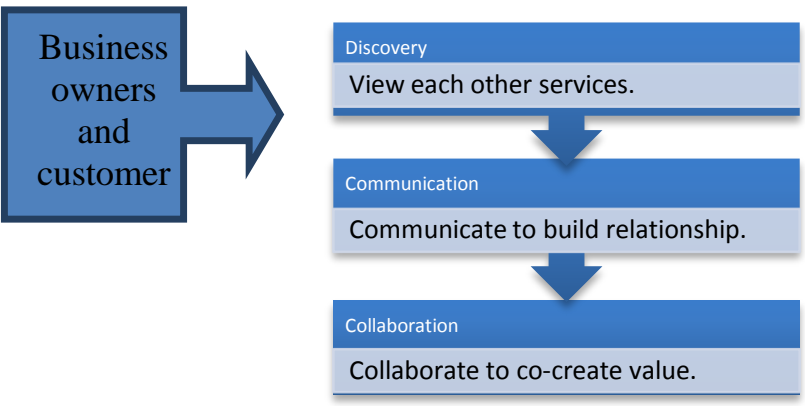

Fig 1: The DCC Social Commerce Model

\subsubsection{Discovery}

Discovery is the ability of business owners and their customers to view the service presented from both of them. To do this, business owners and their customers are interacting with each other. This interaction makes them use each other services and resources, which creates interdependence between them. Interdependence is important for achieving value co-creation, and to create long relationships. The importance of the Discovery phase in the DCC model for business owners and their customers is to allow them to discover interdependencies in their relationship. The following criteria are chosen from the previous value cocreation frameworks to develop the Discovery phase:

- $\quad$ From Attributes for Value Co-creation (AVC) [18] Complementary competencies are how business owners and their customers providing the right expertise and judgment for each other.

Congruence of expectation means business owners 
expectations of their customers must meet the customers understanding of business owners expectations of them and vice versa.

\section{- $\quad$ From the DART model [19]}

Risk-benefit assessment, which is customers' ability to assess risk and benefits of services and products. Transparency, which is sharing information with customers about services and products to build trust with them.

- From Process-Based framework [21]

Customer value-creating processes are about all resources, practices, and process that used by customers to do their activities.

\subsubsection{Communication}

In this phase, the relationship between business owners and their customers must build on trust, obligation, and communication to increase the strength of relationships to be long term. Long relationships are increasing the possibility of getting more benefits from each other; misunderstanding is reduced, maximize value co-creation. The following criteria are chosen from the previous value co-creation frameworks to build Communication phase:

- $\quad$ From Attributes for Value Co-creation (AVC) [18]

- Behavioral transformation when business owners and their customers have to able to transform behaviors for each other for efficiencies and effectiveness.

- $\quad$ From the DART model [19]

- Dialogue is participation and interaction between business owners and their customers.

- $\quad$ From Process-Based framework [21]

- Encounter processes encounter processes of exchange and interaction.

\subsubsection{Collaboration}

Collaboration is the ability of business owners and their customers to offer resources and knowledge to each other. After the business owners and their customers discover what they offer to each other, they collaborate to co-create value. The collaboration is fundamental for business owners and their customers' relationship to success. The following criteria are chosen from the previous value co-creation frameworks to develop the Collaboration phase:

- $\quad$ From Attributes for Value Co-creation (AVC) [18]

- Perceived control means each one of business owners and their customers has a perception of control.

- $\quad$ From the DART model [19]

- Access which is allowing customer from around the world to access information about services and products providing by business owners

- $\quad$ From Process-Based framework [21]

- Supplier value-creating processes are about all resources, practices, and process that used by firms to deal with customers and partners

Finally, the model is build to facilitate business owners implementing their social commerce sites and co-create value with their customers. To ensure the DCC model working for social commerce e-marketplaces sites the technological features must be identified, and then map them to the DCC model. Next section will explore social commerce emarketplaces technological features in detail.

\subsection{Social Commerce E-Marketplace Technological Features}

For the DCC model to be effective in social commerce emarketplaces, it is mapped with social commerce emarketplaces technological features [29] [30] [31]. The features are divided into five main groups: attraction and promotion features, self-identity creation and communication features, content generating features, collaborative working features, and e-commerce features. Attraction and promotion features promote products and services by other consumers. Self-identity creation and communication features let customers start communication with others and allow them to build self-identity. Content generating features create usergenerated content to help customers in buying decision. Collaborative working features concentrate collective and group work. (see Table 1)

Table 1: Social Commerce E-Marketplace Technological Features and Their Explanation

\begin{tabular}{|c|c|}
\hline Technological Features & Explanation \\
\hline $\begin{array}{c}\text { - Demographic Filtering } \\
\text { (DF) } \\
\text { - Content-Based Filtering } \\
\text { (CBF) }\end{array}$ & $\begin{array}{l}\text { The website lets customers } \\
\text { give their reviews on } \\
\text { products } \\
\text { - The website allows } \\
\text { customers to rate products. } \\
\text { - Shapes the relationship } \\
\text { between customers and } \\
\text { items using specific } \\
\text { methods } \\
\text { - Discover regularity among } \\
\text { profiles of customers who } \\
\text { like certain things. } \\
\text { - This method builds } \\
\text { recommendations by } \\
\text { analyzing a set of rated } \\
\text { data. } \\
\text { - This method assumes that } \\
\text { an object should be } \\
\text { suggested to a customer if } \\
\text { it was rated as relevant by a } \\
\text { group of customers with a } \\
\text { profile similar to the given } \\
\text { customer, provided he has } \\
\text { not yet rated it. } \\
\text { - Get feedback from the } \\
\text { customer about their } \\
\text { experiments on the website. } \\
\text { - This button likes the } \\
\text { website content. } \\
\text { - Lets people comment on } \\
\text { content websites using the } \\
\text { Facebook account } \\
\text { - Show a customer the most } \\
\text { commented items by other } \\
\text { customers. } \\
\text { application beside the } \\
\text { original website. } \\
\text { custome the increase of } \\
\text { viewed items by other } \\
\text { Because the }\end{array}$ \\
\hline
\end{tabular}




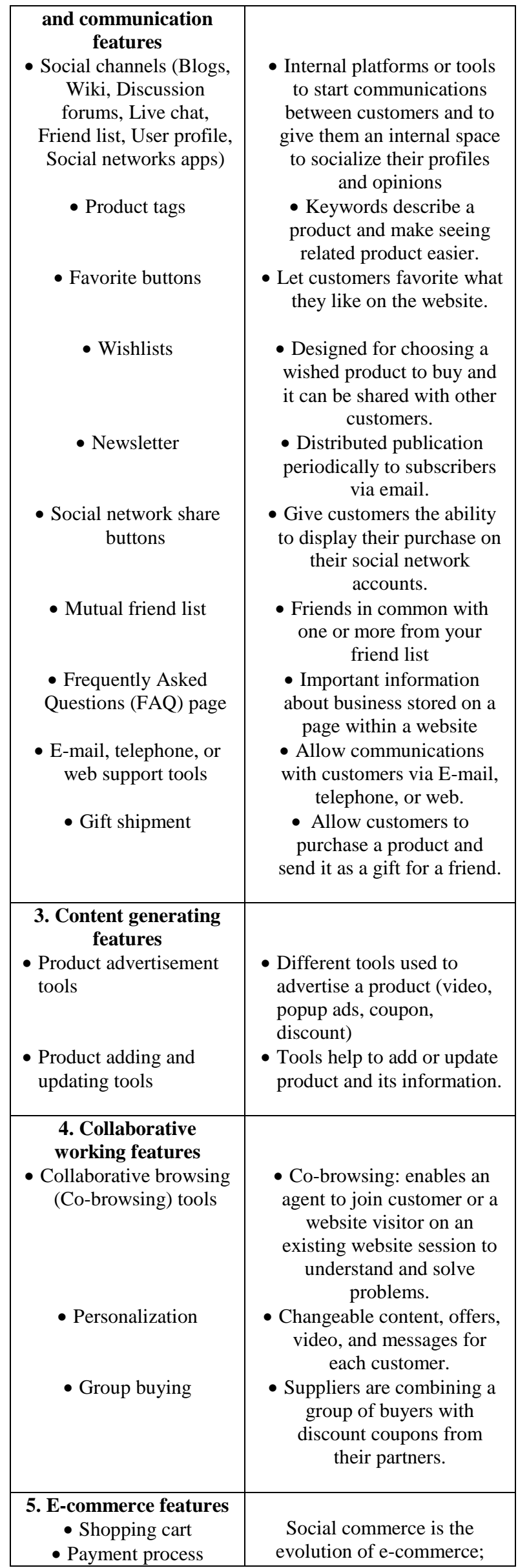

\begin{tabular}{|c|c|}
\hline - E-catalog & because of that social \\
- Shipping policy & commerce websites used \\
- Search functionality & some of the e-commerce \\
- Delivery and returns & features. \\
information & \\
- Security features & \\
- Customization & \\
\hline
\end{tabular}

\subsection{The Mapping between The DCC Model and Technological Features}

To understand how the DCC model works, each phase is mapped to the relevant technological features based on the matching between their definitions. The mapping makes the DCC model effective and useful for social commerce emarketplaces. Table 2 shows the mapping between the DCC model and technological features in detail.

Table 2: Mapping between The DCC Model and Technological Features

\begin{tabular}{|c|c|}
\hline The DCC Model & Technological Features \\
\hline $\begin{array}{c}\text { Discovery } \\
\text { - Risk-benefit assessment }\end{array}$ & $\begin{array}{l}\text { - Attraction and promotion } \\
\text { features }\end{array}$ \\
\hline - Transparency & - E-commerce features \\
\hline $\begin{array}{c}\text { - Complementary } \\
\text { competencies } \\
\text { - Congruence of expectation }\end{array}$ & $\begin{array}{l}\text { - Attraction and promotion } \\
\text { features } \\
\text { - Attraction and promotion } \\
\text { features }\end{array}$ \\
\hline $\begin{array}{l}\text { - Customer value-creating } \\
\text { processes }\end{array}$ & $\begin{array}{l}\text { - Attraction and promotion } \\
\text { features }\end{array}$ \\
\hline $\begin{array}{l}\text { Collaboration } \\
\text { - Access }\end{array}$ & $\begin{array}{l}\text { - Self-identity creation and } \\
\text { communication features, } \\
\text { Content generating } \\
\text { features, and E-commerce } \\
\text { features }\end{array}$ \\
\hline - Perceived control & $\begin{array}{c}\text { - Self-identity creation and } \\
\text { communication features } \\
\text { and Collaborative working } \\
\text { features }\end{array}$ \\
\hline $\begin{array}{l}\text { - Supplier value-creating } \\
\text { processes }\end{array}$ & $\begin{array}{l}\text { - Content generating } \\
\text { features, Collaborative } \\
\text { working features, and E- } \\
\text { commerce features. }\end{array}$ \\
\hline $\begin{array}{l}\text { Communication } \\
\bullet \text { Dialogue }\end{array}$ & $\begin{array}{c}\text {-Self-identity creation and } \\
\text { communication features }\end{array}$ \\
\hline - Behavioral transformation & $\begin{array}{c}\text {-Collaborative working } \\
\text { features }\end{array}$ \\
\hline - Encounter processes & $\begin{array}{c}\text {-Self-identity creation and } \\
\text { communication features }\end{array}$ \\
\hline
\end{tabular}




\section{CONCLUSION}

To develop new products or services successfully, business owners should use value co-creation with their customers. There are a lot of frameworks for value co-creation, but these frameworks are not given a role in technology in their structures. Social commerce e-marketplaces technological features help business owners to personalize customers' experiences of value co-creation, to analyze the behavior of their customers, and to make them participate in product or services innovation process. In general, technology is an important factor for value co-creation to be effective. Thus, there is a need to build a model combining social commerce e-marketplaces technological features and value co-creation process. The DCC social commerce model is developed to serve this purpose. The next stage of the work will be testing the model and analyzing the test result to prove its effectiveness in real-world social commerce websites.

\section{REFERENCES}

[1] Turban, E., King, D., Lee, J. K., Liang, T. P., \& Turban, D. C. (2018). Electronic commerce: A managerial and social networks perspective. Springer.

[2] Liberati, D. (2009). Networked Experiments in Global EScience. In Handbook of Research on Electronic Collaboration and Organizational Synergy (pp. 615-625). IGI Global.

[3] Kaur, A., Dunning, J., Bhattacharya, S., \& Ahmed, A. (2005). 6Re-purposeable learning objects based on teaching and learning styles. In Encyclopedia of Multimedia Technology and Networking (pp. 882-886). IGI Global.

[4] Hajli, M. N. (2014). The role of social support on relationship quality and social commerce. Technological Forecasting and Social Change, 87, 17-27.

[5] Stephen, A. T., \& Toubia, O. (2010). Deriving value from social commerce networks. Journal of marketing research, 47(2), 215-228.

[6] Wang, C., \& Zhang, P. (2012). The evolution of social commerce: The people, management, technology, and information dimensions. CAIS, 31(5).

[7] Afrasiabi Rad, A., \& Benyoucef, M. (2011). A model for understanding social commerce. Journal of Information Systems Applied Research, 4(2), 63.

[8] Chen, A., Lu, Y., \& Wang, B. (2017). Customers' purchase decision-making process in social commerce: A social learning perspective. International Journal of Information Management, 37(6), 627-638.

[9] Yahia, I. B., Al-Neama, N., \& Kerbache, L. (2018). Investigating the drivers for social commerce in social media platforms: Importance of trust, social support and the platform perceived usage. Journal of Retailing and Consumer Services, 41, 11-19.

[10] Liang, T. P., Ho, Y. T., Li, Y. W., \& Turban, E. (2011). What drives social commerce: The role of social support and relationship quality. International Journal of Electronic Commerce, 16(2), 69-90.

[11] O'reilly, T. (2005). What is web 2.0. https://www.oreilly.com/pub/a/web2/archive/what-isweb-20.html. Retrieved 11th November 2018.

[12] Vargo, S. L., Maglio, P. P., \& Akaka, M. A. (2008). On value and value co-creation: A service systems and service logic perspective. European management journal, 26(3), 145-152.

[13] Hassan, S., \& Toland, J. (2013). A conceptual framework for value co-creation practices in $\mathrm{C} 2 \mathrm{C}$ social commerce environment. In 24th Australasian Conference on Information Systems (ACIS) (pp. 1-12). RMIT University.

[14] Lubrica, M. A., Mukhtar, M., \& Abdullah, S. (2011). The EEE encounter model: Applying the service dominant logic to B2B e-marketplaces. Journal of Service Science Research, 3(1), 49.

[15] Prahalad, C. K., \& Ramaswamy, V. (2004). Co-creation experiences: The next practice in value creation. Journal of interactive marketing, 18(3), 5-14.

[16] Flor, N. V., \& Maglio, P. P. (2004). Modeling business representational activity online: A case study of a customer-centered business. Knowledge-Based Systems, 17(1), 39-56.

[17] Lyons, K., \& Tracy, S. (2013). Characterizing organizations as service systems. Human Factors and Ergonomics in Manufacturing \& Service Industries, 23(1), 19-27.

[18] Ng, I.C. \& Yip, N., 2009, B2B performance-based contracts in services: the attributes of value cocreation. Quality in Services Symposium

[19] Prahalad, C. K., \& Ramaswamy, V. (2004). Co-creating unique value with customers. Strategy \& leadership, 32(3), 4-9.

[20] Ramaswamy, V. (2008). Co-creating value through customers' experiences: the Nike case. Strategy \& leadership, 36(5), 9-14.

[21] Payne, A. F., Storbacka, K., \& Frow, P. (2008). Managing the co-creation of value. Journal of the academy of marketing science, 36(1), 83-96.

[22] Payne, A.F., Storbacka, K. \& Frow, P., 2009, Cocreating brands: Diagnosing and designing the relationship experience. Journal of Business Research, 62(3) pp.379-389.

[23] Vargo, S.L., \& Lusch, R.F., 2004, evolving to a new dominant logic for marketing. Journal of marketing, 68(1) pp.1-17.

[24] Huang, Z., \& Benyoucef, M. (2013). From e-commerce to social commerce: A close look at design features. Electronic Commerce Research and Applications, 12(4), 246-259.

[25] Baghdadi, Y. (2016). From e-commerce to social commerce: a framework to guide enabling cloud computing. Journal of theoretical and applied electronic commerce research, 8(3), 12-38.

[26] Kao, T. Y., Yang, M. H., Wu, J. T. B., \& Cheng, Y. Y. (2016). Co-creating value with consumers through social media. Journal of Services Marketing, 30(2), 141-151.

[27] Desai, D. (2009). Role of relationship management and value co-creation in social marketing. Social Marketing Quarterly, 15(4), 112-125.

[28] Schiavone, F., Metallo, C., \& Agrifoglio, R. (2014) Extending the DART model for social 
International Journal of Computer Applications (0975 - 8887)

Volume 181 - No. 31, December 2018

media. International Journal of Technology Management, 66(4), 271-287.

[29] Ismail, N. B., \& Dahlan, H. M. (2017, May). Technical features for social commerce website. In Student Project Conference (ICT-ISPC), 2017 6th ICT International (pp. 1-5). IEEE.
[30] Friedrich, T., Overhage, S., Schlauderer, S., \& Eggs, H. (2015, May). Selecting Technologies for Social Commerce: Towards a Systematic Method. In ECIS.

[31] Curty, R. G., \& Zhang, P. (2013). Website features that gave rise to social commerce: a historical analysis. Electronic commerce research and applications, 12(4), 260-279. 